\title{
The effects of variable light and lipids on the water column distribution and interactions of phytoplankton
}

\author{
Cody Bartlett Smith, Kalina Marinova Manoylov \\ Department of Biological and Environmental Sciences, Georgia College and State University, Milledgeville, GA 31061
}

Email address:

Kalina.manoylov@gcsu.edu(K. M. Manoylov)

\section{To cite this article:}

Cody Bartlett Smith, Kalina Marinova Manoylov. The Effects of Variable Light and Lipids on the Water Column Distribution and Interactions of Phytoplankton. Plant. Vol. 1, No. 2, 2013, pp. 16-24. doi: 10.11648/j.plant.20130102.12

\begin{abstract}
The mechanisms and stimuli that control buoyancy and population numbers in planktonic diatoms are poorly understood. Light, lipids, biovolume, size, and ion regulation have been suggested as possible mechanisms controlling water column distribution. In this study, changes in buoyancy of algae grown as combinations of mono and mixed cultures were measured along with the effects of a varying light direction on the water column distribution of the planktonic diatoms Thalassiosira sp. 1, Thalassiosira pseudonana and Staurosira construens var. venter. Clonal populations were grown in monoculture or in factorial combinations under top and bottom light conditions. No difference in water column distribution or growth between samples exposed to light from above or light from bellow was observed. Oil played an insignificant role in buoyancy regulation. The only species that was buoyant throughout the study was Thalassiosira sp. 1. The larger size and surface area-to-volume ratio of this species indicates a relationship between an increase in buoyancy and increased biovolume. Species specific water column distributions were observed between the monoculture study and the mixed culture study, indicating species specific interactions among phytoplankton may play a significant role in influencing their water column distribution and their degree of buoyancy.
\end{abstract}

Keywords: Buoyancy, Lipids, Thalassiosira sp. LB 2054, Thalassiosira Pseudonana LB FD2, Staurosira Construens var. Venter

\section{Introduction}

Primary producers in both marine and freshwater systems depend on their vertical water column position for overall survival and growth $[1,2]$. Phytoplankton commonly exhibit diel migrations [3] in which algae reside in the upper regions of the photic zone during the day when sunlight is most intense. This is followed by a nocturnal decrease in buoyancy when they descend the nutrient poor surface waters to deeper water where nutrients are more readily available [4]. Cell sinking is considered to be a survival strategy where cells enter resting stages in deeper, colder and darker water where they wait for conditions like light intensity become more favorable again [5]. Therefore, the ability to remain suspended in the upper waters of the photic zone as well as sink to deeper waters is essential for the long-term survival of planktonic diatoms.

The phytoplankton is made up of a diverse algal community. These include organisms such as dinoflagellates and cryptomonads with flagella that allow them to move up and down through the water column to find light, nutrients, and other resources [6], as well as prokaryotic cyanobacteria that inflate and deflate gas vesicles, called aerotops, that can be inflated and deflated to influence their water column distribution [7]. However, diatoms have no flagella during vegetative stages to assist in buoyancy regulation [8]. Additionally, they are unique in the phytoplankton community in that their cell walls are made of heavy silica, $\rho=2070 \mathrm{~kg} \mathrm{~m}^{-3}$ [9], contributing to a typical diatom cells density, $\rho=1085 \mathrm{~kg} \mathrm{~m}^{-3}$, making it significantly denser than seawater, $\rho=1025.6 \mathrm{~kg} \mathrm{~m}^{-3}$ [10], and giving them negative buoyancy. Several experiments contributed to the understanding of how diatoms are capable of staying buoyant and suspended in the water column $[11,12]$. Four mechanisms have been proposed to explain planktonic diatoms ability to maintain and increase their buoyancy: a large cellular surface-to-volume ratio assisted by the presence of rigid, siliceous spines; the formation of chains; the accumulation and storage of lipids; and an active ion regulation that controls the density of the central vacuole by substituting heavier ions with lighter ones. 
[13] found a strong relationship between increased buoyancy and increased cell diameter in Rhizosolenia spp. This is counter to Stoke's Law [1], which states that the velocity of a diatom should be proportional to the square of its radius. Therefore, larger cells should sink faster than smaller cells. Yet, in Thalassiosira pseudonana Hasle \& Heimdal, a small diatom, and Thalassiosira weissflogii (Grunow) Fryxell \& Hasle, a medium-sized diatom, no correlation between sinking rate and cell volume was found [14]. Additionally, in the large diatom Ditylum brightwellii (West) Grunow, the increase in bio volume was related to increased buoyancy [15]. The relationship between increased buoyancy and increased cell diameter is counter to Stoke's Law and could likely be explained by the fact that the excess density of a diatom resides mainly in the silica wall and that the volume of the cell wall relative to the total volume of the cell decreases with increasing cell size [16]. Additionally, the large vacuole of the cell may have a lower density than the cytoplasm. Therefore, as the relative volume of the vacuole increases with the size of the cell, the overall cell density decreases.

The presence of long siliceous spines has been shown to decrease the sinking rate of planktonic diatoms [17]. Cells of Rhizosolenia lacking terminal spines sink faster than the spine-bearing forms, and those with one spine sink faster than those with two spines. This happens by increasing the surface-to-volume ratio and the amount of drag that the cell experienced as it sank in the water column [1]. Chain formation has also shown to decrease the sinking rate of the marine diatom Skeletonema [18]. Diatom chain formations make more relative surface area available. If the cells in a chain can be thought of as one single cell with a large surface area and volume instead of several small cells attached to one another with small surface areas and volumes, it would therefore sink at a slower rate. Similarly, [13] found that larger cells sink at slower rates than smaller cells as cell size and ascent rate were directly related. However, the presence of spines and chain formation does not appear to be the full explanation of slower sinking rates of long colonies of planktonic diatoms. [17] showed that increasing chain length in common genera like Thalassiosira, Nitzschia, Bacteriastrum, and Chaetoceros is associated with an increased sinking rate.

The role of lipids as an energy reserve mechanism in diatoms has been extensively researched and is well understood [19-23]. Under stressful conditions, photosynthetic energy is diverted from cellular growth and redirected to pathways that lead to fatty acid synthesis. These high energy fatty acids are essential for the survival of the cell during unfavorable conditions when light, nutrients, water, and other resources are no longer available in large quantities. Lipids, $\rho_{\mathrm{L}}=860 \mathrm{~kg} \mathrm{~m}^{-3}$ [10], are significantly less dense than seawater and should allow cells to achieve positive buoyancy; however, cellular production of lipids as a mechanism of buoyancy regulation has not been found in previous research [24]. [11] demonstrated that cells that had accumulated the most lipids tended to settle to the bottom of the culture. [1] determined that even in cells that produce exceptionally high amounts of oil, the changes to their overall densities are insufficient to make diatoms less dense than seawater.

Fluctuations of levels of starches, dense carbohydrates within cells, have been indicated as a buoyancy control mechanism. [25] found that carbohydrate content affects the buoyancy of cyanobacteria. Cyanobacterial cells regulate their sinking rates with high carbohydrate cells sinking and low carbohydrate cells remaining more buoyant. In Thalassiosira weissflogii, it was found that volume and carbon content were not primary determinants of variation in cell sinking rates [15]. In Thalassiosira weissflogii, that as carbohydrates like starch increased, the sinking rates of the cells increased [26]. The lack of a relationship between the sinking rate and carbohydrate content in the diatoms $T$. weissflogii and Ditylum brightwellii has been reported [14].

One of the most extensively studied buoyancy mechanisms is the metabolically regulated selective control of intracellular ions. [12] suggested that planktonic diatoms could reduce their densities to where their specific gravity is equal to seawater by exchanging heavier divalent ions for lighter monovalent ions (e.g. $\mathrm{Na}^{+}$and $\mathrm{K}^{+}$) in the fluids of its central vacuole (cell sap). Ditylum brightwellii has been shown to maintain low sinking rates by using cellular energy while in exponential growth and loses the ability to maintain a low sinking rate when deprived of light [28]. [24] found that neutral buoyancy cannot be achieved solely by regulating concentrations of common inorganic ions as proposed by [12]. Instead, the incorporation of ammonium derivatives with inorganic ions reduces cellular densities, allowing cells to approach neutral or positive buoyancy [24].

There is no one mechanism that is solely responsible for maintaining the buoyancy of all species of planktonic diatoms and algae in general. As part of diel vertical migrations, phytoplankton communities change their water column distribution based off of light and nutrient levels. However, little research has been done to determine what would happen if the light direction were reversed and placed below the planktonic cells. Would they remain buoyant in the upper water column or would they follow a light source from below, sinking in the process? Additionally, there are other factors that can influence buoyancy that have not been properly addressed. Species interact with each other while in the natural environment. Species with similar requirements compete with each other for the limited resources such as light and nutrients leading to decline in their performance measured as reproduction, growth, or survival [29-32]. The effects of competition among different species can influence water column distribution and buoyancy of natural populations but have not been thoroughly studied in the lab. Furthermore, although [11] found that lipids are not a main factor in buoyancy regulation, planktonic diatoms have been known to produce lipids in quantities up to $40 \%$ dry cell weight 
[33] and the effects that such a large amount of oil can have on buoyancy should not be underestimated. In this study, it is hypothesized that light direction, lipid production and interspecies interactions will influence the water column distribution of planktonic species. The objectives of this study were to determine if a buoyancy related movement within the water column can be stimulated by the direction of incoming light, to understand if there is a relationship between lipid production and buoyancy, and to evaluate the role community composition plays on species specific buoyancy.

\section{Materials and Methods}

\subsection{Species}

Samples of Thalassiosira sp. 1 and Thalassiosira pseudonana were ordered from the culture collection of algae at the University of Texas (Thalassiosira sp. strain \# LB 2054, Thalassiosira pseudonana strain \# LB FD2). Additionally, a culture of Staurosira construens var. venter (Ehrenberg) Hamilton was developed in the lab (Plate 1). The species were chosen because they are all planktonic diatoms and the genome of Thalassiosira pseudonana is one of only a few algal species to have its genome sequenced [34]. Species from the genus Thalassiosira including $T$. pseudonana have been used in several studies on buoyancy and sinking rates in the past [14, 15, 26, 27]. Additionally, T. pseudonana has been identified as a potential model organism for large scale lipid/biofuel production $[22,35]$.

Thalassiosira sp. 1 resembles Thalassiosira weissflogii in that it fits within the broad diameter range of 4-32 $\mu \mathrm{m}$, its valve is almost flat, and it has fine areole. However, Thalassiosira sp. 1 has a variable number of fultoportulae ranging from 0-6 and with the large range in size from the original description, Thalassiosira sp. 1 cannot be identified as Thalassiosira weissflogii. Thalassiosira pseudonana is a small centric diatom ranging from $2-9 \mu \mathrm{m}$. Its shell structure is difficult to see under LM and contains oblong areole that varies in length in the central part of the valve. Staurosira construens var. venter is an araphid planktonic diatom with lanceolate valves with rostrate ends. The valve face is flat, or slightly undulate due to raised costae. The striae are distinct, alternate and composed of oval areole decreasing in size from the valve face/mantle edge to both the central sternum and the valve mantle.

Thalassiosira pseudonana, and Thalassiosira sp. 1 exhibit a wide range of salinity tolerances and are commonly found in marine and brackish waters. In this study the algae were grown in a solution consisting of Bold's medium (Sigma-Aldrich Scientific, Inc, Saint Louis, MO) and Alga-Gro® Seawater medium (Carolina Biological Supply Company) in a 50:50 mixture. A sample of each algal culture was digested and identified for verification under standard protocols [36]. The cleaned frustules were mounted on permanent slides using
Naphrax ${ }^{\circledR}$ resin (Brunel Microscopes Inc., Chippenham, Wilshire, UK) and were identified under 1000X magnification (Leica Microsystems Inc., Buffalo Grove, Illinois). Permanent slides from each monoculture were prepared and deposited as part of the diatom slide collection of the GCSU Natural History Museum. A live sample was taken from each culture and counted to determine the initial density.

Master cultures of Thalassiosira sp. 1, T. pseudonana and Staurosira construens var. venter were created by inoculating $5 \mathrm{~mL}$ of the ordered UTEX samples into 100 $\mathrm{mL}$ of a mixed Bold's medium and Alga-Gro ${ }^{\circledR}$ Seawater medium solution. The cultures were maintained under 75.0 $\mu \mathrm{mol} \mathrm{m} \mathrm{m}^{-2} \mathrm{~s}^{-1}$ using Kessil H150 LED grow lights (Kessil Lighting, Richmond, CA) under 24:0 light:dark cycle and were exposed to room temperature $\left(20^{\circ} \mathrm{C}\right)$. The cultures were grown for three weeks prior to the study to ensure exponential growth in order to supply the required biomass for the experimental studies. Bio-volumes of the three cultures were recorded by measuring the length and width of 100 frustules of each species at random in girdle view.

Bio-volume was calculated by approximating the shape of the centric diatoms to a cylinder and using the formula

$$
V=\pi / 4 \cdot d^{2} \cdot h
$$

where $V$ is volume, $d$ is diameter and $h$ is height [37].

\subsection{Monoculture Study}

Thalassiosira sp. 1, T. pseudonana, and Staurosira construens var. venter were inoculated into separate 10.0 $\mathrm{mL}(1.0 \mathrm{~cm} \times 10.0 \mathrm{~cm})$ test tubes to identify the spatial distribution characteristics of each individual species.

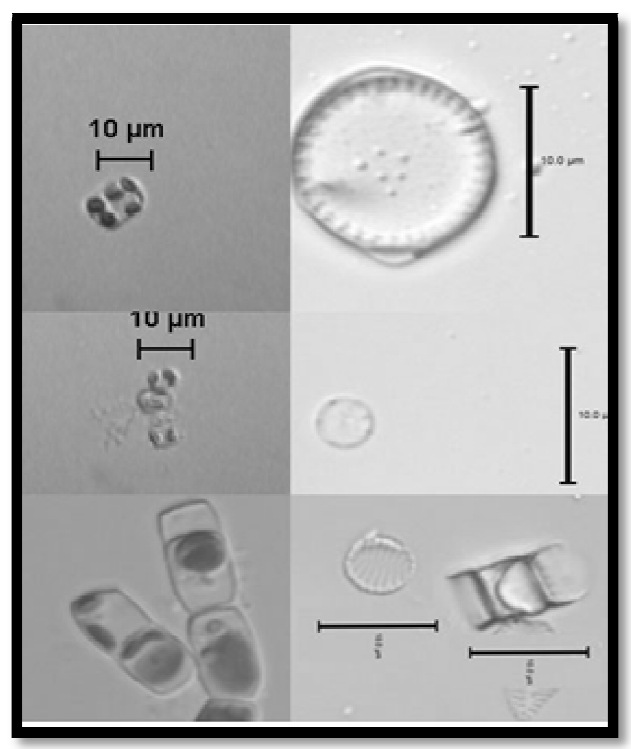

Plate 1. 1-2. Thalassiosira sp.1. live and digested in valve view. 3-4. Thalassiosira pseudonana live and digested in valve view. 5-7. Staurosira construens var. venter live, digested in valve view, and digested in fiddle view. 1, 3. Images taken at 400X magnification. 2, 4, 5-7. Images taken at $1000 X$ magnification. Scale bars $=10 \mu \mathrm{m}$. 
To determine the influence of variable light conditions on water column distribution, each species was subjected to a limited light source with either 'top light' only or 'bottom light' only. The samples for each treatment were replicated in triplicate. This created a total of six test tubes for each species, three top light only and three bottom light only and eighteen overall. Aluminum foil was wrapped over the test tubes to allow light into only the top $1 \mathrm{~cm}$ or bottom $1 \mathrm{~cm}$ of the test tubes (Preliminary runs of this experiment were performed to ensure the validity of this method). The monoculture and mixed culture samples were grown in a Percival I-36 Series Controlled Environment Chamber Incubator (Percival Scientific Inc, Perry, IA) using Philips Alto II 25 Watt bulbs with a light intensity of $1.647 \mu \mathrm{mol}$ $\mathrm{m}^{-2} \mathrm{~s}^{-1}$ on a $14: 10$ light:dark cycle, $64 \%$ relative humidity and a temperature of $18^{\circ} \mathrm{C}$ (Fig. 2).

\subsection{Mixed Culture Study}

The Thalassiosira cultures were mixed with each other to study the inter-species relationships among the algae. Starting from the same master cultures as the monoculture study, $2 \mathrm{~mL}$ of each Thalassiosira species was mixed together to create new cultures of Thalassiosira sp. 1. and $T$. pseudonana, Thalassiosira sp. 1. and Staurosira construens var. venter, Staurosira construens var. venter and $T$. pseudonana. Additionally, $1.33 \mathrm{~mL}$ of each monoculture was added to create a culture of Thalassiosira sp. 1, T. pseudonana, and Staurosira construens var. venter. The cultures were covered with aluminum foil in a similar fashion as the monocultures experiment to create top light only samples and bottom light only samples. The samples for each treatment were replicated in triplicate.

The studies were run over a 15-day period with the number of cells present at three heights in the water column counted every three days totaling five counting events. Water column distribution was evaluated at the heights of $0.3 \mathrm{~cm}, 2.5 \mathrm{~cm}$, and $4.7 \mathrm{~cm}$ from the bottom of the test tube. The heights were used to create a measurable gradient along the water column and were slightly below the surface and above the test tube bottom to ensure that the sampled cells were buoyant rather than settled on the bottom. The $4.7 \mathrm{~cm}$ sample (the top sample) was taken first followed by the $2.5 \mathrm{~cm}$ sample (the middle sample) and then the $0.3 \mathrm{~cm}$ sample (the lowest sample) to ensure that the height being sampled did not disrupt the unsampled heights (Fig. 2). The cell numbers recorded represent only those alive with visible chloroplasts actively growing and remaining buoyant. For both the monoculture and mixed culture study, $1 \mathrm{~mL}$ of medium was added to each test tube halfway through the study to offset water loss due to evaporation. To determine densities, 100 frustule counts were performed for the water column heights of each triplicate on $400 \mathrm{X}$ magnification from a $0.1 \mathrm{~mL}$ sample using a $0.1 \mathrm{~mL}$ Palmer-Maloney nannoplankton counting chamber. If 100 valves were not present, ten random fields of view were counted. At the end of the study, after all final measurements were taken for sample day 5; final densities were calculated to include all cells for each species by shaking the test tubes to redistribute both buoyant and nonbuoyant cells. Statistical analyses of data were performed using two-way ANOVA (SYSTAT 1998).

\subsection{Oil}

Oil densities in each monoculture were counted on the third and fifth sampling days (days 9 and 15 of growth) at all three water column heights. Oil densities were calculated as a percentage as a measure of the volume of all of the oil droplets present in the cells compared to the total bio-volume of the cell [37]. The diameter of all oil droplets was approximated to a sphere and measured, as well as the length and diameter of the cell.

\section{Results}

\subsection{Monoculture Study}

The average cell bio-volume of each species was calculated. The bio-volume of Thalassiosira sp. 1 was $2,219 \pm 185.88 \mu^{3}$, T. pseudonana was $98 \pm 14.16 \mu \mathrm{m}^{3}$, and Staurosira construens var. venter was $767 \pm 250.34$ $\mu \mathrm{m}^{3}$. A comparison between the initial and the final densities of Thalassiosira sp. 1, T. pseudonana, and Staurosira construens var. venter show that all three species experienced increase in densities (Fig. 1). Staurosira construens var. venter increased in density the most while $T$. pseudonana increased the least. Each culture experienced an increased density from the start of the study to the finish. Thalassiosira sp. 1, Staurosira construens var. venter and $T$. pseudonana maintained their unique identifiable characteristics including bio-volume and morphology throughout the study.

There was no significant effect of variable light on growth (ANOVA, $\mathrm{p}=0.211$ ). There was no significant difference in the water column distribution to the varying light source between the three species Thalassiosira sp. 1, T. pseudonana, and Staurosira construens var. venter (ANOVA $\mathrm{p}=0.729$ Fig. 2).

A significant difference in the water column distribution between Thalassiosira sp. 1, Thalassiosira pseudonana, and Staurosira construens var. venter was observed (ANOVA $\mathrm{R}^{2}=59.24, \mathrm{p}<0.0001$ Fig. 2).

Only Thalassiosira sp. 1 remained buoyant throughout the study. The $0.3 \mathrm{~cm}$ and $2.5 \mathrm{~cm}$ heights exhibited a consistent biomass of approximately $7.5 \times 10^{6} \mu \mathrm{m}^{3}$ during the five sampling events while the $4.7 \mathrm{~cm}$ height exhibited a decline in the number of cells from the first sample event to the last. Thalassiosira pseudonana and Staurosira construens var. venter settled to the bottom of the test tube by the first sampling event and remained there through the remainder of the study. 


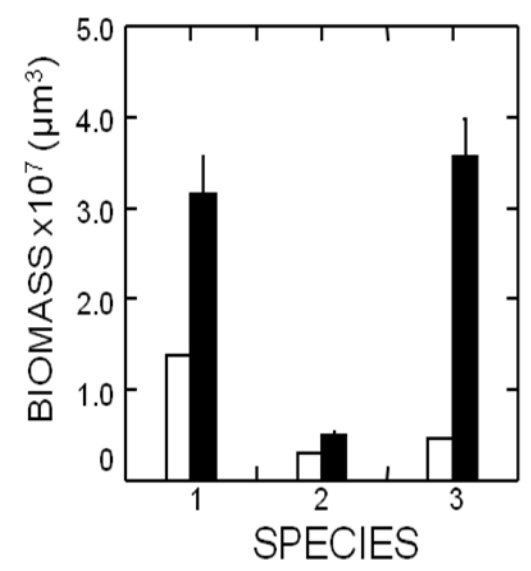

Figure 1. The initial (white) to final (black) growth of top light monoculture samples of Thalassiosira sp. 1 (1), Thalassiosira pseudonana (2), and Staurosira construens var. venter (3).

\subsection{Mixed Culture Study}

In the three species mixed samples, Thalassiosira sp. 1, T. pseudonana and Staurosira construens var. venter remained suspended in the water column to various extents (Figs. 3 and 4). Thalassiosira sp. 1 remained positively or neutrally buoyant and suspended in the water column in all cultures. Thalassiosira pseudonana was buoyant, concentrating towards the bottom of the test tube in the $0.3 \mathrm{~cm}$ height when competing with Thalassiosira sp. 1 (Figs. 3 and 4).

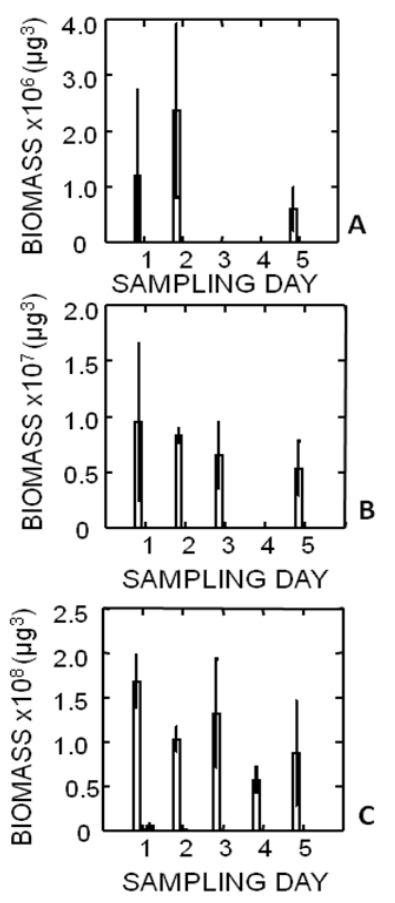

Figure 2. The total biomass per sample of Thalassiosira sp. 1 (white), Thalassiosira pseudonana (grey), and Staurosira construens var. venter (black) over the course of the monoculture study with top light. A. $4.7 \mathrm{~cm}$, B. $2.5 \mathrm{~cm}$ C. at $0.3 \mathrm{~cm}$.

Staurosira construens var. venter was buoyant, concentrating towards the bottom of the test tube when competing with Thalassiosira $s p .1$ as well as when competing with T. pseudonana (Figs. 3 and 3). When $T$. pseudonana and Staurosira construens var. venter were grown together, both species were negatively buoyant, settled out of the water column and remained along the bottom of the test tube throughout the study. Light source direction did not have an effect on the water column distribution of the Thalassiosira species.

All three species of Thalassiosira increased in biomass over the course of the study to varying degrees (Fig. 5). Thalassiosira sp. 1 and Staurosira construens var. venter grew in all mixed cultures while $T$. pseudonana only grew in the mixed culture with all three species.

When cultured with only Thalassiosira sp. 1 and only Staurosira construens var. venter, T. pseudonana was alive but did not divide, showing no net growth. Staurosira construens var. venter experienced the greatest growth while T. pseudonana experienced the least. The growth of Thalassiosira sp. 1, T. pseudonana and Staurosira construens var. venter was less than in the individual monocultures. Light from neither above the test tubes nor below was not a factor affecting the population increase of the algal cells.

A growth rate calculation was attempted for the monoculture study and the mixed culture study. However, due to cells falling out of solution and settling to the bottom of the test tube, they were not able to be counted.
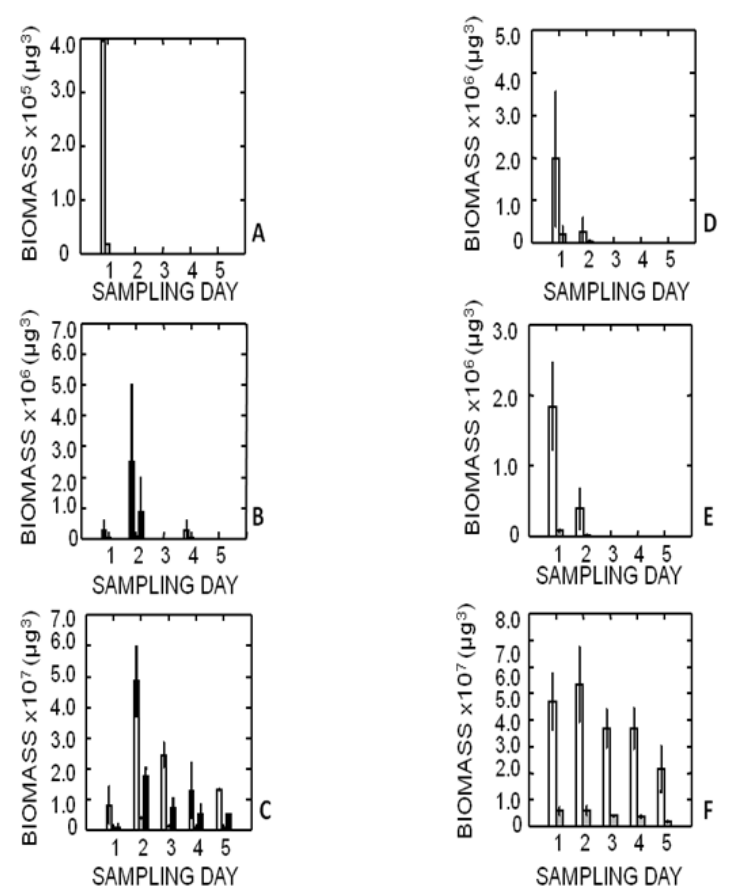

Figure 3. The total biomass per sample of Thalassiosira sp. 1 (white), Thalassiosira pseudonana (grey) and Staurosira construens var. venter (black) (Left) and Thalassiosira sp. 1 and Thalassiosira pseudonana (Right) over the course of the top light mixed culture study. A and D. $7 \mathrm{~cm}$, $B$ and $E .2 .5 \mathrm{~cm} C$ and $F .0 .3 \mathrm{~cm}$.

Instead, a comparison between the initial starting density and the final density is used to identify cell growth over time (Figs. 1 and 5). 


\subsection{Oil}

Oil data was not collected from Thalassiosira pseudonana and Staurosira construens var. venter because they were not buoyant at the time of the sampling. Thalassiosira sp. 1 remained buoyant and exhibited oil synthesis during the study. The total percentage bio-volume of oil in cells buoyant at the $0.3 \mathrm{~cm}$ height, $19.3 \pm 2.8$, was higher than the cells buoyant at the $2.5 \mathrm{~cm}$ height, $5.1 \pm 1.8$ (Fig. 6). There was a significant difference in the percentage of oil produced $(p=0.0011)$.

\section{Discussion}

\subsection{The Effects of Varying Light}

In this study, covering the test tubes so that only overhead light could be used for photosynthesis was used to simulate the direction that cells would be exposed to sunlight in a natural setting. Additionally, the bottom light group of test tubes was covered so light could only enter from the bottom to determine if planktonic diatoms could be encouraged to lower their water column position as a result of following light from below. However, no water
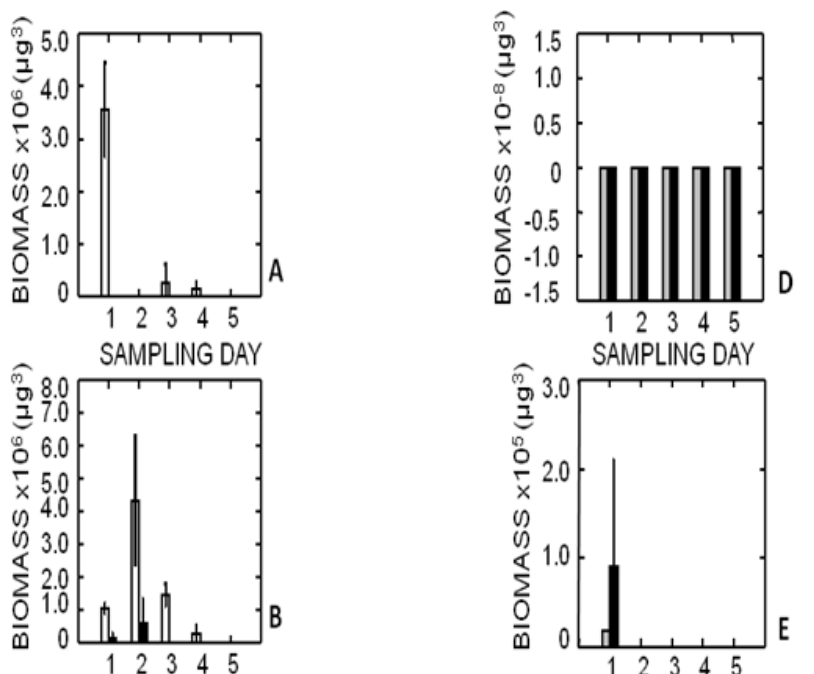

SAMPLING DAY

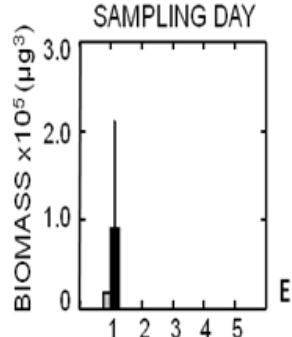

SAMPLING DAY
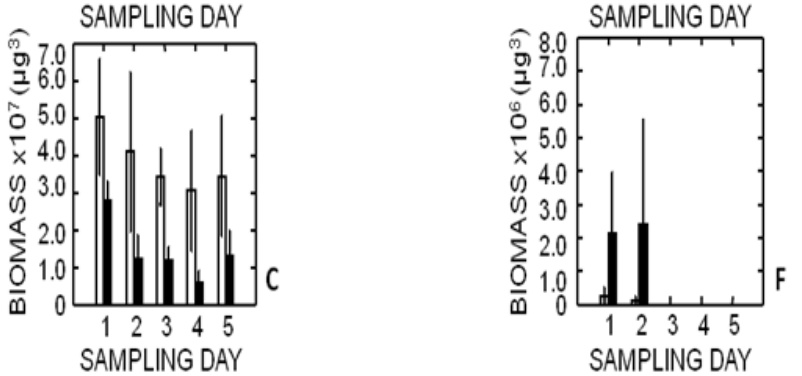

Figure. 4. The total biomass per sample of Thalassiosira sp. 1 (white) and Staurosira construens var. venter (black) (Left) and Thalassiosira pseudonana (grey) and Staurosira construens var. venter (Right) over the course of the top light mixed culture study. A and D. $4.7 \mathrm{~cm}, B$ and E. 2.5 $\mathrm{cm}$ and $C$ and $F .0 .3 \mathrm{~cm}$.

water column distribution gradient was observed between cells exposed to overhead light compared to those exposed

to light from below in both the monoculture and mixed culture studies. Furthermore, light source direction was not a factor affecting the growth rate of the monocultures or mixed cultures. The lack of a difference between top light samples and bottom light samples in water column distribution and growth rate is likely due to the absence of a light gradient being established between the top of the test tube and the bottom. Although a low light level was used to ensure that the bottom received less light than the top $\left(1.647 \mu \mathrm{mol} \mathrm{m} \mathrm{m}^{-2} \mathrm{~s}^{-1}\right)$, the results indicate that the test tubes were potentially too short to create a significant light gradient that would affect the diatom cells. The similar growth rates between top light cultures and bottom light cultures support this.

\subsection{Monoculture Study}

Only Thalassiosira sp. 1 remained consistently buoyant over the course of the study. Both T. pseudonana and Staurosira construens var. venter settled to the bottom after inoculation. Additionally, Thalassiosira sp. 1 has a much larger bio-volume $\left(2,219 \pm 185.88 \mu^{3}\right)$ compared to $T$. pseudonana $\left(98 \pm 14.16 \mu^{3}\right)$ and Staurosira construens var. venter $\left(767 \pm 250.34 \mu^{3}\right)$ consistent with the biovolume findings of [15]. The increased buoyancy in Thalassiosira sp. 1 is likely due to its increased surface to volume ratio. [1] found that large, buoyant cells have a slower sedimentation rate than smaller cells. [12] first noticed this relationship and determined that it must be related to the size of the vacuole and cell sap in larger cells. The larger the cell and therefore, the larger the vacuole and cytoplasm, the greater the ability of the less dense protoplast of the cell to compensate for the weight associated with the heavy silica cell wall. Studies have shown that some of the largest planktonic algal cells are the most strongly buoyant and can ascend several meters per hour [38-40].

Thalassiosira sp. 1, T. pseudonana and Staurosira construens var. venter exhibited an increase in the total biomass from the beginning of the study to the end. This growth indicates that the cells were receiving enough light and nutrients from culture conditions to photosynthesize and reproduce. The planktonic diatoms T. pseudonana and Staurosira construens var. venter settled along the bottom of the test tube as opposed to staying buoyant in the water column as would be expected of planktonic diatoms. This may be an indication that buoyancy is being regulated by bio-volume in accordance to Stoke's Law. As bio-volume increases, the buoyancy of the cell should increase. As a result, smaller cells do not have a large enough bio-volume to achieve neutral or positive buoyancy. In this study, the large bio-volume of Thalassiosira sp. 1 appears to be large enough to achieve neutral/positive buoyancy, allowing it to be suspended in the water column. However, the smaller bio-volumes of T. pseudonana and Staurosira construens var. venter appear to not be sufficient enough to achieve buoyancy through this mechanism and settled to the bottom. 


\subsection{Mixed Culture Study}

The water column distribution among Thalassiosira pseudonana and Staurosira construens var. venter differed in their mixed culture samples from their monoculture water column distributions while Thalassiosira sp. 1 remained consistent across both. While T. pseudonana and Staurosira construens var. venter settled to the bottom and out of the water column in the monoculture experiment, both remained buoyant when in the presence of Thalassiosira $s p$. 1. In the culture consisting of all three species, Thalassiosira sp. 1 remained buoyant with the most cells present in the water column while Staurosira construens var. venter increased its buoyancy considerably compared to monocultures. Thalassiosira pseudonana exhibited a small water column distribution and remained buoyant. In the Thalassiosira sp. 1 and Thalassiosira pseudonana culture, Thalassiosira pseudonana exhibited a similar degree of buoyancy and water column distribution without Staurosira construens var. venter as with the three species mixed culture. Similar to Thalassiosira pseudonana, Staurosira construens var. venter exhibited a similar water column distribution and degree of buoyancy when mixed with just Thalassiosira sp. 1. When T. pseudonana and Staurosira construens var. venter were mixed together, neither was buoyant and both species settled along the bottom of the test tube. Although both Thalassiosira pseudonana and Staurosira construens var. venter settled to the bottom in the monoculture study, the lack of buoyancy when they are grown together suggests that neither species out-competed the other at the bottom of the test tube. Furthermore, the different water column distributions exhibited by Thalassiosira pseudonana and Staurosira construens var. venter depending on which other species they were mixed with highlights that water column distribution was influenced by species specific interactions. Several mechanisms have been researched that could have lead to the increase in buoyancy observed in $T$. pseudonana and Staurosira construens var. venter samples mixed with Thalassiosira $s p$. 1, although the exact method is unclear. Species within the genus Thalassiosira are known to produce chitin filaments that can be used to connect to form chains [34]. In a similar manner that siliceous spines are used to increase the surface area to volume ratio and increase drag in some planktonic species, the much lighter chitinous filaments could be used to create drag, decreasing the sinking rate of Thalassiosira pseudonana and Staurosira construens var. venter and increasing its buoyancy [8]. Although chitinous filaments were not observed connecting cells in chains, the transparent filaments could have been present in the absence of chains. Additionally, small diatoms may use an active ion regulation proposed by [12] and further researched by [24]. Without a large bio-volume to overcome the weight of a dense silica cell wall like in larger diatoms, smaller cells may actively select for
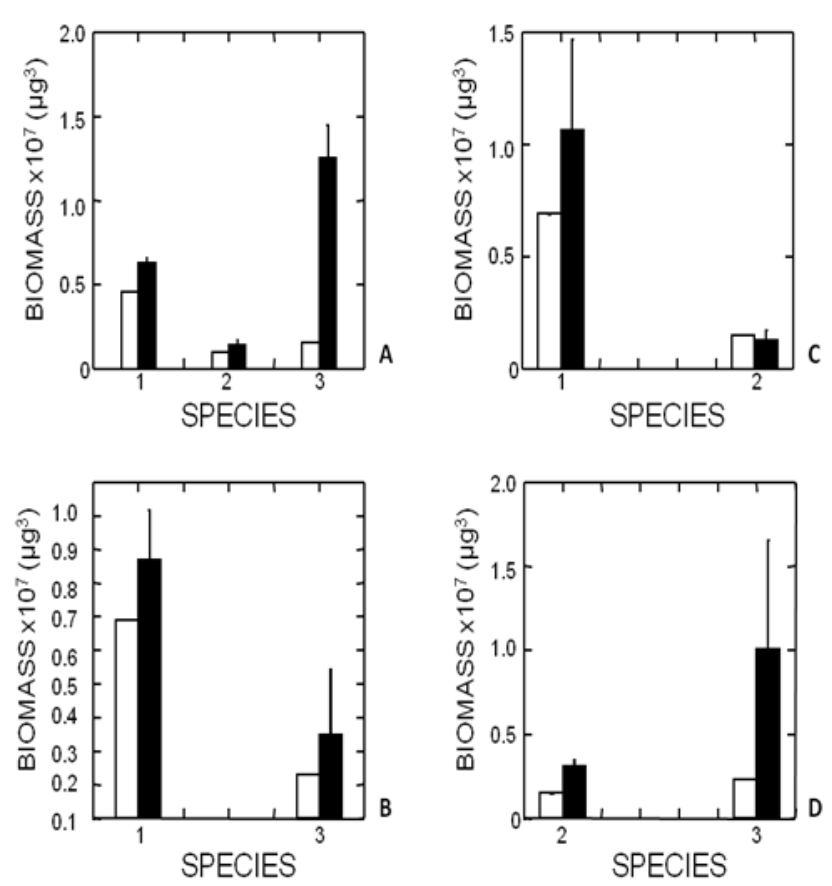

Figure 5. The initial (white) to final (black) growth of top light mixed culture samples of Thalassiosira sp. 1 (1), Thalassiosira pseudonana (2) and Staurosira construens var. venter (3). A. Thalassiosira sp. 1, T. pseudonana, and Staurosira construens var. venter. B. Thalassiosira sp. 1 and Staurosira construens var. venter. C. Thalassiosira sp. 1 and T. pseudonana. D. T. pseudonana and Staurosira construens var. venter.

lighter ions and ammonia derivatives to decrease the density of the cytoplasm, increasing buoyancy. lighter ions and ammonia derivatives to decrease the density of the cytoplasm, increasing buoyancy.The altered water column distribution and degree of buoyancy among Thalassiosira pseudonana and Staurosira construens var. venter when mixed with Thalassiosira sp. 1 and their lack of buoyancy when mixed together highlights that species specific interaction may play a major role in the regulation of buoyancy among planktonic diatom species. In natural communities, algal species are all adapted to slightly different conditions and use their differences as competitive advantages to outcompete other species for a limited amount of light, nutrients, and space in the photic zone. The effects from these species specific interactions are a strong factor that may influence the buoyancy of the phytoplankton and is often overlooked in buoyancy studies. Several studies have investigated many aspects that affect buoyancy in planktonic diatoms from oil production, ion regulation, the presence of spines and chains, and carbohydrate content. However, these studies were done almost exclusively in monoculture experiments where inter-species interactions were excluded $[4,11,14,28,41]$ and the effects of species specific interactions forces were not addressed or investigated.

\subsection{Oil}

Oil densities were measured from the monocultures on 
sampling date three in order to allow the cells to adjust to the culture conditions. Buoyant cells at $4.7 \mathrm{~cm}$ and 2.5 $\mathrm{cm}$ from each species were to have their oil densities compared to $0.3 \mathrm{~cm}$ cells. However, only Thalassiosira sp. 1 had cells with a large enough biomass of cells buoyant on sample dates three to follow through with the comparison. The buoyant cells of Thalassiosira sp. 1 at $2.5 \mathrm{~cm}$ had a lesser percentage of oil than did $0.3 \mathrm{~cm}$ cells. Cells at the $0.3 \mathrm{~cm}$ height were producing larger amounts of oil than were more buoyant cells at the 2.5 $\mathrm{cm}$ height indicating that the low density of oil $\left(\rho_{\mathrm{L}}=860\right.$ $\mathrm{kg} \mathrm{m}^{-3}$ ) does not play a role in the buoyancy regulation. These findings are similar to the work of [11] and others. [11] also found that cells sink most rapidly when lipid concentrations are highest. The highest sinking rates found in their study were in cells with the highest amount of lipids. Lipids have been observed accumulating in cells under senescent conditions in which cells tended to settle to the bottom of the culture [42].

\section{Conclusion}

In this study, a lack of a light gradient mitigated the effects of a variable light source and limited the effect of light on buoyancy. Thalassiosira sp. 1 cells that produced the most oil were lower in the water column than cells producing less oil. Oil was determined to not play a significant role in increasing buoyancy. None of the three Thalassiosira species were observed producing large spines at any point of the study, limiting their contributions to influence or increase buoyancy as proposed by [1] Therefore, although an increased surface area from spines or chains may assist or play a role in buoyancy regulation, their presence is not required for cells to remain buoyant and suspended in the water column. The only species

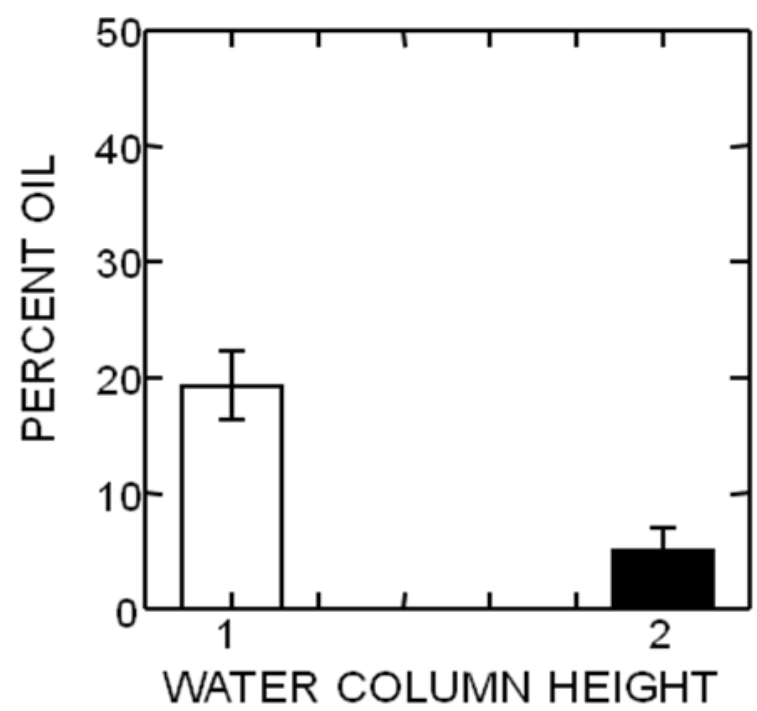

Figure 6. The oil density percentage and water column distribution of Thalassiosira sp. 1 (0.3 cm is white. $2.5 \mathrm{~cm}$ is black). that was consistently buoyant in this study was Thalassiosira sp. 1. Its large bio-volume and low surface to volume ratio compared to the others suggests a strong relationship between an increase in buoyancy associated with larger size. Finally, the different water column distributions observed between the monoculture study and the mixed culture study indicate that species specific interactions among phytoplankton may play a significant role in influencing their water column distribution and their degree of buoyancy.

\section{References}

[1] T. J. Smayda. "The sinking and suspension of phytoplankton in the sea," Oceanogr. Mar. Bio. Annu. Rev. vol 8, pp. 353414. 1970.

[2] E Walsby and C. S. Reynolds. "Sinking and floating," In: Moris I (ed) The Physiological Ecology of Phytoplankton. University of California Press, Los Angeles. pp. 371-412. 1980.

[3] D. Blasco, "Observations on the diel migrations of marine dinoflagellates off the Baja Californaia Coast," Mar Bio. Vol, 46. pp. 41-47. 1978.

[4] T. L. Richardson and J. J. Cullen. "Changes in buoyancy and chemical composition during growth of a coastal marine diatom: ecological and biogeographical consequences," Mar Ecol-Prog Ser. vol. 128, pp. 77-90. 1995.

[5] V. S. Smetacek. "Role of sinking in diatom life-history cycles: ecological, evolutionary and geological significance," Mar Biol. vol, 84, pp. 239-251. 1985.

[6] J. J. Cullen. "Diel vertical migration by dinoflagellates: role of carbohydrate and behavioral flexibility," In: Rankin MA (ed) Migration: Mechanisms and Adaptive Significance. Contr. Mar. Sci. vol. 27, pp. 135-152. 1985.

[7] A. E. Walsby. "Gas vesicles," Microbial Rev. vol 58, pp. 94144. 1994.

[8] F. E. Round, R. M. Crawford, and D. G. Mann. The Diatoms: Biology and Morphology of the Genera. Cambridge University Press. Cambridge, UK. 1990.

[9] J. C. Lewin. Silicification. In: Lewin R (ed) Physiology and Bichemistry of Algae. Academic, New York. 40, pp. 21-53. 1962.

[10] J. R. Raven. Vacuoles: Storage, Flotation, and Amplification of Surface/Volume Ratio of Cytoplasm. In: energetic and Transport in Aquatic Plants. Liss, New York. pp. 411-470. 1984.

[11] W. J. Anderson and B. M. Sweeney. "Diel changes in sedimentation characteristics of Ditylum brightwellii: changes in cellular lipid and effects of respiratory inhibitors and ion-transport modifiers," Limnol Oceanogr, vol. 22, pp. 539-552. 1977.

[12] F. Gross and E. Zeuthen. "The buoyancy of planktonic diatoms: a problem of cell physiology," P R Soc B. vol. 135, pp. 382-389. 1948.

[13] J. K. Moore and T. A. Villareal. "Size-ascent rate 
relationships in positively buoyant marine diatoms," Limnol Oceanogr. vol. 41, pp. 1514-1520. 1996.

[14] E. Fisher, J. A. Berges, and P. J. Harrison. "Does light quality affect the sinking rates of marine diatoms?" J Phycol. vol. 32, pp. 353-360. 1996.

[15] M. Waite, A. Fisher, T. A. Thompson, and P. J. Harrison. "Sinking rate versus cell volume relationships illuminate sinking rate control mechanisms in marine diatoms," Mar Ecol- Prog Ser. vol. 157, pp. 97-108. 1997.

[16] G. E. Hutchinson. A Treatise on Limnology. Vol. II. Introduction to Lake Biology and Limnoplankton. Wiley, New York, 1115. 1967.

[17] T. J. Smayda and B. Boleyn. "Experimental observation on the flotation of marine diatoms. I. Thalassiosira cf. nana, Thalassiosira rotula and Nitzschia seriata," Limnol Oceanog. vol. 10, pp. 449-509. 1965.

[18] T. J. Smayda and B. Boleyn. "Experimental observation on the flotation of marine diatoms. II. Skeletonema costatum and Rhizosolenia setigera," Limnol Oceanog. vol. 11, pp. 18-34. 1966.

[19] L. B. Brentner, M. J. Eckelman, and J. B. Zimmerman. "Combinatorial life cycle assessment to inform process design of industrial production of algal biodiesel," Environ Sci and Technol. pp. 00-00. 2011.

[20] Y. C. Chen. "The biomass and total lipid content and composition of twelve species of marine diatoms cultured under various environments," Food Chem. vol. 131, pp. 211-219. 2012.

[21] J. L. Csavina, B. J. Stuart, R. G. Riefler, and M. L. Vis. "Growth optimization of algae for biodiesel production," J Appl Microbiol. vol. 111, pp. 312-318. 2011.

[22] M. Hildebrand, A. K. Davis, S. R. Smith, J. C. Traller, and R. Abbriano. "The place of diatoms in the biofuels industry," Adv Biochem Eng Biot. vol. 3, pp. 221-240. 2012.

[23] T. V. Ramachandra, D. M. Mahapatra, and B. Karthick. "Milking diatoms for sustainable energy: biochemical engineering versus gasoline-secreting diatom solar panels," Ind. Eng. Chem. Res. vol. 48, pp. 8769-8788. 2009.

[24] M. Boyd and D. Gradmann. "Impact of osmolytes on buoyancy of marine phytoplankton," Mar Biol. vol. 141, pp. 605-618. 2002

[25] R. L. Oliver. "Floating and sinking in gas-vacuolate cyanobacteria," J Phyc. vol. 30, pp. 161-173. 1994.

[26] R. L. Richardson and J. J. Cullen. "Changes in buoyancy and chemical composition during growth of a coastal marine diatom: ecological and biogeographical consequences," Mar Ecol-Prog Ser. vol. 128, pp. 77-90. 1995.

[27] E. Fisher and J. P. Harrison. "Does carbohydrate content affect the sinking rates of marine diatoms?" J Phycol. vol.

\section{2, pp. 360-365. 1996}

[28] M. Waite, P. A. Thompson, and P. J. Harrison. "Does energy control the sinking rates of marine diatoms?" Limnol Oceanog. vol. 37, pp. 468-477. 1992.

[29] Tilman. "Resource competition between planktonic algae: An experimental and theoretical Approach,". Ecology. vol. 58, pp. 338-348. 1977.

[30] K. Richardson, J. Beardall, and J. A. Raven. "Adaptation of unicellular algae to irradiance, an analysis of strategies," New Phytol. vol. 93, pp. 61-72. 1983.

[31] M. Begon, J. L. Harper, and C. R. Townsend. Ecology. $3^{\text {rd }}$ Edition. Oxford, UK; Blackwell Science. 1996.

[32] K. M. Manoylov. "Intra- and interspecific competition for nutrients and light in diatom cultures," J Freshwater Ecol. vol. 24, pp. 145-157. 2009.

[33] N. S. Shifrin and S. W. Chisholm. "Phytoplankton lipids, interspecific differences and effects of nitrate, silicate, and light-dark cycles," J Phycol. vol. 17, pp. 374-384. 1981.

[34] V. Armburst, J. A. Berges, C. Bowler, et al. "The genome of the diatom Thalassiosira pseudonana: ecology, evolution and metabolism," Science. vol. 306, pp. 79-86. 2004.

[35] L. Borges, J. A. Moron-Villarreyes, D. Montes, M. G. Oca, and P. C. Abreu. "Effects of flocculants on lipid extraction and fatty acid composition of the microalgae Nannochloropsis oculata and Thalassiosira weissflogii," Biomass Bioenerg. vol. 35, pp. 4449-4454. 2011.

[36] G. R. Hasle and G. A. Frxyell. "Diatoms: cleaning and mounting for light and electron micriscopy," Tran. Am. Microsc. Soc. vol. 89, pp. 469-474. 1970.

[37] H. Hillebrand, C. Durselen, U. Pollingher, and T. Zohary. "Biovolume calculation for pelagic and benthic microalgae," J Phyc. vol. 35, pp. 403-424. 1999.

[38] T. A. Villareal. "Positive buoyancy in the oceanic diatom Rhizosolenia H. Peragallo," Deep-Sea Res. vol 35, pp. 1037-1045. 1988.

[39] T. A. Villareal. "Buoyancy properties of the giant diatom Ethmodiscus," J. Plankton Res. vol. 14, pp. 459-463. 1992.

[40] T. A. Villareal, M. A. Altabet, and K. Culver-Rymsza. "Nitrogen transport by vertically migrating diatoms mats in the North Pacific Ocean," Nature. vol. 363, pp. 709-712. 1993.

[41] J. C. Costello and S. W. Chisholm. "The influence of cell size on the growth rate of Thalassiosira weissflogii," J Plankton Res. vol. 3, pp. 415-419. 1981.

[42] J. D. Strickland. "Measuring the production of marine phytoplankton," Bull Fish. Res. Bd. Can. Vol, 122. 1970. 